\title{
Corporate Governance Rating System in Taiwan with Multi-Criteria Decision Making Methods
}

\author{
Hsin-An Su \\ National Taipei University of Technology \\ E-Mail:su192@yahoo.com.tw \\ Chin Hsien Hsieh \\ Chihlee Institute of Techonlogy \\ E-Mail: hsien@mail.chihlee.edu.tw \\ Chih-Yang Chang \\ National Taipei University of Technology \\ E-Mail: chychang@gmail.com \\ Fengyi Lin ${ }^{1}$ \\ National Taipei University of Technology \\ E-Mail: linfengyi.tw@gmail.com
}

\begin{abstract}
Corporate governance has been the subject of extensive research due to high-profile scandals associated in well-known companies. Examining the existed governance rating system in Taiwan, we find that little attention has been paid to the role of corporate governance rating systems and the rating scores are poor predictors in predicting the multiple dimensions of firm performance. This study proposes to use multi-criteria decision-making methods, notably SAW, TOPSIS, and VIKOR, as refined scoring models for a corporate governance rating system. The results show that VIKOR, for its ability to obtain more precise scores, outperforms both the existing methodologies and the other two MCDM approaches.
\end{abstract}

Keywords: Corporate Governance, Multi-Criteria Decision Method, Related-Party Transaction

\footnotetext{
${ }^{1}$ Corresponding Author
} 


\section{INTRODUCTION}

In the wake of recent corporate embezzlement scandals and the resulting public focus on firm's corporate governance, managers have been pressured by their clients to incorporate corporate governance mechanism. In recent years, healthy corporate governance mechanisms have become the trend in international asset markets. There have been numerous recent attempts by rating services to quantify the quality of corporate governance in firms with commercially available ratings. A study by Ying-hua Ye et. al. (2002) was based on corporate governance theory and used quantitative methods, evaluating the positive incentive effects and negative occupation effects of major investors in order to evaluate the corporate governance of Taiwan's listed companies. The governance scores have become increasingly popular among retail investors, supply vendors and regulators since the corporate scandals erupted. Surprisingly, there is little systematic study of the value of these third-party governance ratings in assessing firm performance. This study utilized the multi-criteria decision-making models for corporate governance and compared them with traditional weighted average scoring methods, aiming to provide more precise rating systems.

\section{Related Literature Corporate Governance and Ratings}

The Organization for Economic Cooperation and Development (2004) defined corporate governance as "a system for managing and supervising enterprises". Corporate governance describes in detail the responsibilities and corresponding power distribution relationships of participants in the enterprise (e.g. board of directors, management levels, investors, and other stakeholders) and lays out the regulations and procedures that should be incorporated into company policy (Ertugrul\&Hedge,2009). Recently, several papers have examined the relationship between firm performance and a composite measure of corporate governance. Brown and Caylor (2006) construct a governance score using Institutional Shareholder Services governance factors. They find that firms with lower governance scores have a higher return on equity and higher profit margins. Gompers, Ishii, and Metrick (2003) find that firms with fewer shareholder rights have lower stock returns and firm valuation.

The CLSA corporate governance rating (2001) involves use of the survey design rating method, utilizing clear yes or no answers in order to reduce the subjective influence of analysts. Standard and Poor's strengthened its corporate governance rating services in 2001 by utilizing survey questionnaire design methods. Deviating from the survey questionnaire methods of CLSA and Standard and Poor's, Ye et al. 
(2002), adopted corporate governance theory as a basis and attempted to use quantitative methods to evaluate positive incentive effects and negative occupation effects of major investors, incorporating considerations such as Taiwanese stock ownership frameworks, board compositions and major shareholder behavior. The corporate governance rating systems may not be performed sufficiently and exactly, because the available data and information are vague, inexact, imprecise and uncertain by nature. To resolve the vagueness, ambiguity, and subjectivity of human judgment in corporate governance rating scores, MCDM approaches are introduced to express the linguistic terms in decision-making process.

\section{Multiple Criteria Decision Making (MCDM)}

Multiple-attribute utility is based on the composite goals formed by different attributes and is judged according to utility maximization. Multiple attribute decision making methods determine the optimal solution through evaluating the relative importance of different attributes. In this paper, we contribute to the literature by presenting a comprehensive analysis of governance ratings provided by existing Taiwan rating vendors.

\section{Research Methods and Design}

This study used five dimensions and seventeen variables as rating indicators based on the corporate governance system established by Ye et al. (2002). The SAW, TOPSIS, and VIKOR MCDM methods were used to compare differences in and advantages of existing corporate governance rating systems.

\section{Existing Corporate Governance Rating Methods}

We adopted the existing Taiwan rating systems, most of which used Ye et al.'s corporate governance grading system as a representative of existing grading methods. This grading method was based on 17 corporate governance variables. Companies are classified into ten groups based on sample size. The largest group is given 10 points and the smallest group given 1 point. If a variable is inversely related to company performance, then the tested companies are ranked according to that variable from the least to the greatest and divided into ten groups based on sample size. The smallest group is given 10 points. A high score for a tested company indicates good operation of corporate governance mechanisms. 


\section{VIKOR Method}

VIKOR was presented by Opricovic (Opricovic \& Tzeng, 2004), and belongs to the optimized compromise programming group of MCDM methods. The basic concept lies in first defining the ideal solution (positive-ideal solution) and the negative ideal solution (worst solution, negative-ideal solution). The method is as follows

A. Finding positive ideal solution and negative ideal solution

$$
\begin{aligned}
& \mathrm{f}_{\mathrm{i}}^{+}=\left[\left\langle\max _{\mathrm{j}} \mathrm{f}_{\mathrm{ij}} \mid \mathrm{i} \in \mathrm{I}_{1}\right\rangle,\left\langle\min _{\mathrm{j}} \mathrm{f}_{\mathrm{ij}} \mid \mathrm{i} \in \mathrm{I}_{2}\right\rangle\right] \forall i \\
& \mathrm{f}_{\mathrm{i}}^{-}=\left[\left\langle\min _{\mathrm{j}} \mathrm{f}_{\mathrm{ij}} \mid \mathrm{i} \in \mathrm{I}_{1}\right\rangle,\left\langle\max _{\mathrm{j}} \mathrm{f}_{\mathrm{ij}} \mid \mathrm{i} \in \mathrm{I}_{2}\right\rangle\right] \forall i
\end{aligned}
$$

$\mathrm{j}$ : each company; $\mathrm{i}$ : each rating criteria; $\mathrm{f}_{\mathrm{ij}}$ : the performance rating value of the company for the $\mathrm{i}^{\text {th }}$ rating criteria; $\mathrm{I}_{1}$ : the set of utility rating criteria, $\mathrm{I}_{2}$ : the set of cost rating criteria.

$$
\begin{aligned}
& \text { B. Calculating } \mathrm{S}_{\mathrm{j}} \text { and } \mathrm{R}_{\mathrm{j}} \\
& \left.\mathrm{s}_{\mathrm{j}}=\sum_{\mathrm{i}=1}^{\mathrm{n}} \mathrm{w}_{\mathrm{i}}\left\{\left(\mathrm{f}_{\mathrm{i}}^{*}-\mathrm{f}_{\mathrm{ij}}\right) / \mathrm{f}_{\mathrm{i}}^{*}-\mathrm{f}_{\mathrm{i}}^{-}\right)\right\} \forall \mathrm{j} \\
& \left.\mathrm{R}_{\mathrm{j}}=\operatorname{Max}\left[\mathrm{w}_{\mathrm{i}}\left(\mathrm{f}_{\mathrm{i}}^{*}-\mathrm{f}_{\mathrm{ij}}\right) / \mathrm{f}_{\mathrm{i}}^{*}-\mathrm{f}_{\mathrm{i}}-\right)\right] \forall \mathrm{j}
\end{aligned}
$$

$\mathrm{W}_{\mathrm{i}}$ represents the relative weight of each rating criteria

$$
\begin{aligned}
& \text { C. Calculating } Q_{j} \\
& Q_{j}=v\left[\left(S_{j}-S^{*}\right) /\left(S^{-}-S^{*}\right)\right]+(1-v)\left[\left(R_{j}-R^{*}\right) /\left(R--R^{*}\right)\right] \forall j
\end{aligned}
$$

This compromise solution is stable within a decision making process, which could be "voting by majority rule" (when v. $>0.5$ is needed), or " by consensus" $\mathrm{v} \sim 0.5$, or " with veto" $(\mathrm{v}$. $<0.5)$. Here, $\mathrm{v}$ is the weight of the decision making strategy "the majority of criteria" (or "the maximum group utility").

$$
\begin{aligned}
& \mathrm{S}^{*}=\operatorname{Min}_{\mathrm{j}} \mathrm{S}_{\mathrm{j}} ; \mathrm{S}^{-}=\operatorname{Max}_{\mathrm{j}} \mathrm{S}_{\mathrm{j}} \\
& \mathrm{R}^{*}=\operatorname{Min}_{\mathrm{j}} \mathrm{R}_{\mathrm{j}} ; \mathrm{R}^{-}=\operatorname{Max}_{\mathrm{j}} \mathrm{R}_{\mathrm{j}}
\end{aligned}
$$

The value obtained by $\operatorname{Min}_{\mathrm{j}} \mathrm{S}_{\mathrm{j}}$ is maximum group utility, while the value obtained by $\operatorname{Min}_{\mathrm{j}} \mathrm{R}_{\mathrm{j}}$ is minimum individual regret.

Proposal ordering is performed based on the relationships of $\mathrm{Q}_{\mathrm{j}} \mathrm{S}_{\mathrm{j}}$, and $\mathrm{R}_{\mathrm{j}}$; when 
the following conditions are established, then a smaller $Q_{j}$ is better.

Condition 1: threshold condition of acceptable benefit

$$
Q^{\prime}-Q^{\prime \prime}>1 /(J-1)
$$

After the $Q$ values are ordered, the $S$ value of the first proposal $\left(S^{\prime}\right)$ must also simultaneously perform better than the $S$ value of the proposal ordered second $\left(S^{\prime \prime}\right)$. Alternatively, after the $\mathrm{Q}$ values are ordered, the $R$ value of the first proposal must $\left(R^{\prime}\right)$ also perform better than the $R$ value of the second proposal $\left(R^{\prime \prime}\right)$.

\section{Corporate Governance Rating Indexes}

Taiwan's Corporate Governance and Rating Systems presents a corporate governance rating system based on characteristics of Taiwanese companies (Ye et al, 2002). This system adopts a total of 5 dimensions and 17 variables as follows :

Table 1 Table of Corporate Governance Rating Indexes

\begin{tabular}{|c|c|c|}
\hline Dimension & Variables & $\begin{array}{c}\text { Relationship with } \\
\text { company performance }\end{array}$ \\
\hline \multicolumn{3}{|c|}{ A. Board composition } \\
\hline \multirow[t]{6}{*}{ (40\% weight) } & $\begin{array}{l}\text { 1.Ratio of largest shareholder members serving as } \\
\text { board member }\end{array}$ & Negatively related \\
\hline & $\begin{array}{l}\text { 2.Ratio of professional managers serving as board } \\
\text { members }\end{array}$ & Positively related \\
\hline & $\begin{array}{l}\text { 3.Ratio of other shareholders serving as board } \\
\text { members }\end{array}$ & Positively related \\
\hline & $\begin{array}{l}\text { 4.Ratio of largest shareholder members serving as } \\
\text { supervisors }\end{array}$ & Negatively related \\
\hline & 5.Ratio of other shareholder serving as supervisors & Positively related \\
\hline & 6. Number of supervisors & Positively related \\
\hline \multicolumn{3}{|c|}{ B. Stockholding rights structure } \\
\hline \multirow[t]{2}{*}{ (20\% weight) } & 1.Largest shareholder cash flow rights & Positively related \\
\hline & 2.Deviation of voting rights from cash flow rights & Negatively related \\
\hline \multicolumn{3}{|c|}{ C. Management type } \\
\hline \multirow[t]{2}{*}{ (10\% weight) } & $\begin{array}{l}\text { 1.Largest shareholder members serving as } \\
\text { chairman/CEO }\end{array}$ & Negatively related \\
\hline & 2.Second largest shareholder share proportion & Positively related \\
\hline
\end{tabular}


Table 1 Table of Corporate Governance Rating Indexes (Continued)

\begin{tabular}{lll}
\hline \multicolumn{2}{l}{ D. Unusual related party transactions } & \\
\hline (20\% weight) & 1.Stakeholder stock rights transaction ratio & Negatively related \\
\hline & 2.Unusual stakeholder capital contact ratio & Negatively related \\
\hline & 3.Ratio of unusual stakeholders selling and buying & Negatively related \\
\hline & $\begin{array}{l}\text { 4.Ratio of unusual stakeholders receiving and paying } \\
\text { accounts }\end{array}$ & Negatively related \\
\hline E. Large stakeholder market interventions & Negatively related \\
\hline (10\% weight) & 1.Ratio of large shareholders equity pledge & Negatively related \\
\hline & $\begin{array}{l}\text { 2.Number of listed companies establishing } \\
\text { investment firms }\end{array}$
\end{tabular}

\section{Research Sample}

\section{RESEARCH DESIGN}

Our research proposed to use the existing rating method, which utilizes 17 corporate governance variables as a basis (Table 1). We design 50 virtual companies to test their corporate governance. The group with the largest value is given 5 points and the group with the smallest value 1 point. If a variable is negatively related to company performance, the rules are same. A higher score for a tested company indicates better corporate governance mechanisms. This method is simple but contains certain limitation. When evaluated companies with equal scores, the existing rating system will treat these 50 companies equally as first-rank and thus cannot effectively rate their corporate governance. The interval numbers are more suitable to deal with the decision-making problems in uncertain environment, because they are the simplest form of representing uncertainty in the decision matrix. The interval numbers require the minimum amount of information about the values of the corporate governance attributes.

For validation purpose, we then design 50 virtual companies using indicators derived from corporate governance variables resulting in the same total scores of 60 by the Taiwan's existing rating method. In order to verify the final results consistency with the original design sample, the end digits of the companies are 2 、 7,4 , 9, 1 、6, 3 、 8, 0 、 5 (for example: A2 、A7 、A12 、A17 、A22 、A27 、A32 、A37 、A42 、 A47). The same second digit means those companies are in the same group. 


\section{EMPIRICAL RESULTS}

After establishing the data of 50 companies, we used three different ranking methods -the SAW method, the TOPSIS method, and the VIKOR method to rank the 50 sets of data in terms of corporate governance (Table 2) to find a better solution of corporate governance rating system.

Table 2 Comparison of Rankings Produced by the VIKOR, TOPSIS, and SAW

Methods

\begin{tabular}{cccc|cccc}
\hline Co. & SAW & TOPSIS & VIKOR & Co. & SAW & TOPSIS & VIKOR \\
\hline A1 & 16 & 16 & 26 & A26 & 13 & 13 & 21 \\
\hline A2 & 6 & 6 & 4 & A27 & 3 & 4 & 8 \\
\hline A3 & 37 & 36 & 36 & A28 & 33 & 33 & 32 \\
\hline A4 & 25 & 26 & 16 & A29 & 27 & 23 & 13 \\
\hline A5 & 46 & 46 & 46 & A30 & 43 & 43 & 41 \\
\hline A6 & 15 & 15 & 25 & A31 & 19 & 19 & 29 \\
\hline A7 & 5 & 7 & 6 & A32 & 9 & 2 & 2 \\
\hline A8 & 35 & 35 & 35 & A33 & 38 & 39 & 39 \\
\hline A9 & 26 & 25 & 15 & A34 & 22 & 29 & 19 \\
\hline A10 & 45 & 45 & 45 & A35 & 49 & 49 & 49 \\
\hline A11 & 17 & 17 & 27 & A36 & 12 & 12 & 23 \\
\hline A12 & 8 & 5 & 3 & A37 & 2 & 9 & 9 \\
\hline A13 & 39 & 37 & 37 & A38 & 32 & 32 & 33 \\
\hline A14 & 24 & 27 & 17 & A39 & 30 & 22 & 12 \\
\hline A15 & 47 & 47 & 47 & A40 & 42 & 42 & 43 \\
\hline A16 & 14 & 14 & 24 & A41 & 20 & 20 & 30 \\
\hline A17 & 4 & 8 & 7 & A42 & 7 & 1 & 5 \\
\hline A18 & 34 & 34 & 34 & A43 & 36 & 40 & 40 \\
\hline A19 & 28 & 24 & 14 & A44 & 21 & 30 & 20 \\
\hline A20 & 44 & 44 & 44 & A45 & 50 & 50 & 50 \\
\hline A21 & 18 & 18 & 28 & A46 & 11 & 11 & 22 \\
\hline A22 & 10 & 3 & 1 & A47 & 1 & 10 & 10 \\
\hline A23 & 40 & 38 & 38 & A48 & 31 & 31 & 31 \\
\hline A24 & 23 & 28 & 18 & A49 & 29 & 21 & 11 \\
\hline A25 & 48 & 48 & 48 & A50 & 41 & 41 & 42 \\
\hline & & & & & & \\
\hline
\end{tabular}

As shown in Table 2, all three methodologies can provide effective rankings for each company. However, the rankings' sequences were different. It is impossible for investors to determine which ranking methodologies perform the best. Therefore, we add the conditional $\mathrm{A}^{\prime}-\mathrm{A}^{\prime \prime} \geqq 1 /(\mathrm{J}-1)$ in order to distinguish the superior companies 
with the best corporate governance. By using SAW method, we found that Company A47 (0.7742) had the best corporate governance and that Company A45 (0.5084) had the worst. After adding the conditional, SAW can be used to divide our 50 sample companies in four levels.

By using TOPSIS, we aggregate the weight of evaluation criteria and the matrix of performance to evaluate the 50 companies. It was found that Company A42 (0.7682) had the best corporate governance and A45 (0.3706) the worst. After adding the conditional, TOPSIS can be used to classify these 50 companies into three levels.

Ranking by VIKOR needs to be performed with values of criteria weights and analysis of the impact of criteria weights on the proposed compromise solution. Company A22 (-0.0031) was found to have the best corporate governance and Company A45 (-0.9683) to have the worst. After adding the conditional, VIKOR approach classified these 50 companies into five levels.

Table 3 Values and Rankings Using the VIKOR Method

\begin{tabular}{|c|c|c|c|}
\hline \multirow{2}{*}{ Rank } & \multirow{2}{*}{ Co. } & \multicolumn{2}{|c|}{$\mathrm{A}_{\mathrm{ij}}$} \\
\hline & & Max & Min \\
\hline 1 & $\begin{array}{c}\mathrm{A}_{i j} \\
i=1 \cdot 2 \cdot 3.4 ; j=2.7\end{array}$ & -0.0031 & -0.0277 \\
\hline 2 & $\begin{array}{c}\mathrm{A}_{i j} \\
i=1 \cdot 2 \cdot 3.4 ; j=4.9\end{array}$ & -0.6804 & -0.7177 \\
\hline 3 & $\begin{array}{c}\mathrm{A}_{i j} \\
i=1 \cdot 2 \cdot 3.4 ; j=1 \cdot 6\end{array}$ & -0.7698 & -0.7822 \\
\hline 4 & $\begin{array}{c}\mathrm{A}_{i j} \\
i=1 \cdot 2 \cdot 3 \cdot 4 ; j=3.8\end{array}$ & -0.8711 & -0.9001 \\
\hline 5 & $\begin{array}{c}\mathrm{A}_{i j} \\
i=1 \cdot 2 \cdot 3.4 ; j=0.5\end{array}$ & -0.9570 & -0.9683 \\
\hline
\end{tabular}

From the empirical results of the above three rating methods, it is interesting to discover that when listed companies earned equal scores, the existing rating method was unable to further differentiate the companies. This results in a situation in which the 50 companies were equally ranked. As a result, this study used three other methods for rating. After the conditional $\mathrm{A}^{\prime}-\mathrm{A}^{\prime \prime} \geqq 1 /(\mathrm{J}-1)$ was added, it was found that the VIKOR method could divide the 50 companies into 5 different levels. SAW could divide the 50 companies into 4 different levels, while the TOPSIS method could only classify the companies into 3 different levels.

As a result, the VIKOR method was superior to the other two methods after adding the conditional formula. Though the TOPSIS method could also produce 
rankings, compared with the VIKOR method it was unable to produce further rankings in the second and third levels and provide more precise ranking information. In exploring the reasons for this, we found that SAW and TOPSIS were unable to determine which of the proposals was better and were thus unable to provide more accurate ranking data. To sum up, the final ranking results show that the VIKOR method is the most of the three methodologies in terms of corporate governance rating scoring model, followed by SAW and TOPSIS method.

\section{CONCLUSION}

The findings of this study cover several perspectives. The VIKOR method is the most suitable methodology as a scoring model in a corporate governance rating system. VIKOR can provide effective rating information to the public even when it encounters identical scores of existing corporate governance.

Further investigation and identification of suitable criteria for the corporate governance rating selection problem and the application of other MCDM techniques best suited to improve the quality and effectiveness of decision-making process should be considered for future works. Also, the systematic framework in a fuzzy environment presented in this paper is flexibleand can be easily extended, to be applied to other management decision-making problems.

\section{REFERENCES}

Brown, L. and Caylor, M. L. (2006). Corporate governance and firm performance. Journal of Accounting and Public Policy, 25(4), 409-434. http://dx.doi.org/10.1016/j.jaccpubpol.2006.05.005.

Credit Lyonnais Securities Asia Emerging Markets. (2001). CG Watch: Corporate Governance in Emerging Markets. Saints and Sinners: Who's Got Religion. CLSA Emerging Markets.

Ertugrul, M. and Hegde, S. (2009). Corporate Governance Ratings and Firm Performance. Financial Management, 38(1), 139-160.

Gompers, P., Ishii, J., \& Metrick, A. (2003). Corporate Governance and Equity Prices. Quarterly journal of Economics, 118(1), 107-155. http://dx.doi.org/10.1162/00335530360535162.

Opricovic, S. and Tzeng, G. H. (2004). Compromise solution by MCDM methods: a comparative analysis of VIKOR and TOPSIS. European Journal of Operational Research, 156(2), 445-455. http://dx.doi.org/10.1016/S0377-2217(03)00020-1.

Standard \& Poor's. (2002). Standard \& Poor's Corporate Governance Scores: Criteria, Methodology and Definitions. McGraw-Hill Companies, Inc., 
New York.

The Organization for Economic Cooperation and Development. (2004),OECD Principles of Corporate Governance Publishing. Retrieved Retrieved July 03, 2010, from http://www.oecd.org/corporate/ca/corporategovernanceprinciples/31557724.pdf Ye, Ying-hua, Li, Cun-xiu, and Ke, Cheng-en. (2002). Corporate Governance and Rating Systems. Taipei City: Sun Bright Publishing. 